\title{
Bank Lending Decision under Uncertainty: The Case of Borrowers From European Peripheral Countries in the Sovereign Debt Crisis
}

\author{
Vy Ngoc Tra Nguyen * $\quad$ Long Hai $\mathrm{Vo}^{\dagger}$
}

\begin{abstract}
The European Sovereign Debt Crisis (ESDC) spanning from 2010 to 2012 results in the biggest recession since the Global financial crisis. European countries faced high government debt, rapidly rising yield spreads in government bond, and then the collapse of several European banks. The peripheral countries, Portugal, Ireland, Italy, Greece, and Spain are arguably the most unstable hosting a vast majority of financially troubled borrowers. This paper studies the implications of spillovers from affected local banking systems to other countries which have operations in these troubled economies. Using a comprehensive interbank and international syndicated loan data sample, we find evidence on how changes in the world financial market, in particular the banking industry, alter the lending decisions of local banks. We show that bank tend to tighten their loan terms significantly during the crisis period when the perception of systematic risk changes abruptly. The tightening is also observed to be much stronger for borrowers from European peripheral countries.
\end{abstract}

Keywords: Debt crisis, globalization, bank lending, Probit regression

\section{Introduction}

During the year from 2007 to 2008 when global financial crisis (GFC) the stock market capitalizations of major investment and commercial banks have fall off with more than fifty percent. The crisis severely hurts many global banks and nearly leaded them to being in default. For instance, within the S\&P 1500 list of companies, Bear Stearns, (AIG)American International Group, Lehman Brothers, United Financial Corporation Bank, Downey Financial Corporation, Franklin Bank, and Washington Mutual are all in default between 2007 and $2008^{1}$. These defailts also have significant impact on the global market.For instance, five of Iceland largest banks were nationalized during this time, sharing the same fate as UK's HBOS-Lloyds and Royal Bank of Scotland TBS ${ }^{2}$. Furthermore, the Euro-

\footnotetext{
*Faculty of Economics and Accounting,Quy Nhon University and College of Management, Yuan Ze University.

E-mail: ngocvy@qnu.edu.vn

${ }^{\dagger}$ Corresponding author. Faculty of Finance,Banking and Business Administration, Quy Nhon University.

E-mail: vohailong@fbm.edu.vn.

Acknowledgement: We benefited from the helpful comments made by an anonymous referee. This paper is a revised version of a report written for the Ministry of Science and Technology under the supervision of Professor Chi-Yung Lin, Yuan Ze University. The authors gratefully acknowledge the financial support from the College of management, Yuan Ze University and the University of Western Australia. All errors remain with the authors.

${ }^{1}$ Additionally, FirstFed Financial Corporation, Colonial Bancgroup Inc., CORUS Bankshares Inc., Irwin Financial Corporation, Frontier Financial Corporation, and UCBH Holdings Inc are also default in 2009.

${ }^{2}$ An increasing number of countries, most recently including Portugal and Sri Lanka, likewise nationalized their respective private banks. These nationalization activities were initially aimed at solving the liquidity prob-
} 
pean Sovereign Debt Crisis (ESDC) occurred from 2010 to 2012 lead the the world into the second recession after the GFC. The so-called "peripheral countries" - Ireland, Portugal, Italy, Spain Greece (hereafter PIIGS) - are generally considered the most financially troubled countries during the ESDC. The report of (IMF) shows that "Spillovers from highspread Euro area sovereigns have affected local banking systems but have also spread to institutions in other countries with operations in the high-spread Euro area and with cross-border asset holdings" (International Monetary Fund, 2011). Under the globalization of market, the operation of banks in individual countries will be influenced by the variation of systematic risk of the world market.

In the wake of the globalization of banking system, private debt financing has risen as a dominant source of external funding (Graham, Li, \& Qiu, 2008; Chava, Livdan, \& Purnanandam, 2009). A growing literature investigating determinants of bank finance contracting such as the characteristics of borrowers. These include Bharath, Sunder, and Sunder (2008) who study borrower accounting quality, Graham et al. (2008) who focus on the effect of financial restatement, and Lin, Y, Malatesta, and Xuan (2011) who examine the effect of ownership structure. Furthermore, external factors such as the effect of political connections and the effect of corporate tax avoidance are the topics of Houston, Jiang, Lin, and Y (2014); Hasan, Hoi, Wu, and Zhang (2014). It can be argue that the majority prior studies generally focus on the determinants of the contracts of bank loan from the demand side, i.e. borrowers. In particular, there are only three empirical papers are related to this supply-side issue (Puri, Rocholl, \& Steffen, 2011; Ivashina \& Scharfstein, 2010; Chava \& Purnanandam, 2011). These studies shed light on the loan characteristics and impact of bank, i.e. lenders, on how loan contract terms are made using microstructure loan data type. However, According to our knowledge there is no research that demonstrates whether the variation of systematic risk of the world financial market affects the lending decisions of in the syndicate loan market context.

Much of the recent academic interest is also placed on the literature highlighting the adverse effects of risk and uncertainty perception on investment via the channel of bank lending. Brunnermeier (2009) and Diamond and Rajan (2009) document the restriction of bank lending during the GFC as a result of uncertainty about their liquidity and future investment opportunities, which then contribute to the downturn Studying four large jumps in uncertainty in the US, Raunig, Scharler, and Sindermann (2017) find that bigger and more liquid banks lend less after an increment in uncertainty, as a result of a significant reduction of bank loan supply. The authors argue that this is because smaller banks tend to have greater access to individual customers' creditworthiness information. This is perhaps due to the fact that they engaged in so-called "relation-banking", and stronger bank-customer relationships enhance liquidity. Another related literature is dedicated to understanding banks' leverage behaviour and capital structure in times of crises from a self-insurance perspective. According to Valencia (2016), because of greater costs of external finance during bad times, banks tend to increase their capital buffer when there is uncertainty about future losses and that uncertainty is a strong leverage driver. From the perspective of regulators, counter-cyclical capital requirements may turn out to be effective in restraining banking credit during good times. However, this scheme will overbur-

lems of distressed private banks and restoring public confidence. 
den banks in bad times, since banks have already decreased their leverage as a response to increased uncertainty.

This study attempts to examine whether the variation of systematic risk will affect the lending decisions of banks from the syndicate loan market. In particular, we focus on the impact of the ESDC on the lending decisions of European banks, particularly to PIIGS borrowers. First, we will discuss if the contagion effect exists in the whole European loan market. We expect that total amount of loan issued drop considerably in the European loan market after the ESDC occurred. Second, we expect that bank loan terms will become tighter as a result of the crisis occurred. For example, the banks will charge higher loan spread, reduce the loan maturity, and charge more collateral or more covenants to compensate the higher risk they faced. Finally, we expect that banks in European countries with higher status of financial market integration or high index of economic freedom will be influenced more. Our contribution to the literature is twofold. First, this paper provides a new approach to explain the determinant of bank loan contracts from a supply-side perspective. Different from the literature which focuses on the demand-side of loans, we propose a new factor in the bank loan contracts by using the variation of systematic risk of the world market in the supply-side. This variation is proxied by the difference between bank loans' characteristics before and after the ESCD. Second, this paper complements several recent studies on the lending decisions of banks during the crisis by relating the variation of systematic risk in the sample of global banks. These studies have shown that the banks always reduce the total lending amount and raise the loan reject ratios and loan spreads after crisis occurred (Ivashina \& Scharfstein, 2010; Puri et al., 2011; Chava \& Purnanandam, 2011; Ho, Huang, Lin, \& Yen, 2016). This study indicates that this effect is only significant for low quality borrowers. The rest of the paper assumes the following structure: Section 2 proposes two hypotheses relating the characteristics of bank loan contracts to the characteristics of borrowers. In Section 3, several econometric specifications are adopted to examine the impact of PIIGS borrowers, the ESCD, and their interaction, on multiple important bank loan characteristics. Section 4 describes our syndicated loan data sample and presents some preliminary statistical observations. The primary empirical result is reported in Section 5, which is followed by concluding remarks in Section 6.

\section{Hypothesis Development}

Hypothesis 1: Bank loan terms will become tighter after the crisis had occurred. In particular, the banks will charge higher loan spread, reduce the loan maturity, and charge more collateral or more covenants to compensate the higher risk they faced.

Hypothesis 2: This negative impact of the crisis is stronger for borrowers from the PIIGS countries.

In general, we expect that the change of the systematic risk environment has a strong impact on the lending decision of global banks, especially for countries with financial 
instability in the Europe.

\section{Methodology}

As stated in the previous sections, using a sample of international syndicate loans, our main goal is to discuss whether the occurred of ESDS will impact the lending decisions of European banks. In particular, we focus on the banks' perception of risk, expressed in increasing spread and strict terms, when lending to countries before and after the occurrence of the European Sovereign Debt Crisis (ESDS). We also examine whether this impact is more profound when borrowers come from financially constrained countries, particularly from the peripheral PIIGS. Arguably, while loan terms are influenced by worsen macroeconomic conditions (i.e, crisis) and borrowers' performance (i.e, PIIGS), we cannot rule out the possibility of endogeneity. That is, tighter terms can lead to even worse performance for both the lenders and the borrowers, thus further push the troubled economies into deeper recessions.

With these goals in mind, we divide our sample into two sub-samples: one includes only the banks whose headquarters are located in peripheral European countries (PIIGS) and the other includes the rest of the sample. Of these sub-samples, we further divide them according to the period in which they are made: either "within the time frame of the ESDC (2010-2012)" or "not belong in this period". The number of loans borrowed and their distribution in these four sub-samples are reported in Table 2.

To test the hypotheses specified above, we run the following regression:

$$
\begin{array}{r}
\text { Spread }_{i, t}=\alpha_{0}+\alpha_{1} \text { PIIGS } S_{i, t-1}+\alpha_{2} \text { Crises }+\alpha_{3} \text { PIIGS } S_{i, t-1} \text { Crises }+\beta^{\prime} Z_{i, t-1}+ \\
\gamma_{i}+\mu_{t}+\epsilon_{i, t}
\end{array}
$$

The natural logarithm of bank loan spread for loan $\mathrm{i}$ in year $\mathrm{t}$ is defined by dependent variable in this study (denoted as $\operatorname{Spread}_{i, t}$ ). 1 shows that the value of those countries which belongs to peripheral countries of Europe such as Spain Portugal, Ireland, Greece and Italy by dummy variable and 0 otherwise. The value of 1 shows that the dummy variable of crises if the loan in consideration is made during the period of European Sovereign Debt Crisis (2010 to 2012) and 0 otherwise. $Z_{i, t-1}$ is a vector of control variables for bank $\mathrm{i}$ in year $\mathrm{t}-1 . \gamma_{i}$ and $\mu_{t}$ represent the fixed effects of industry and year, respectively. These control variables are defined in Table 1.

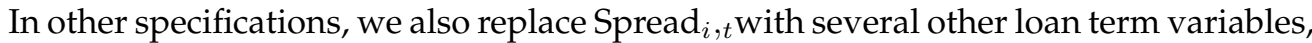
namely, Total cov: the total number of covenants of loan contract, Maturity: the natural logarithm of loan maturity in month, Loansize: the natural logarithm of the amount of loan in millions USD. Furthermore, we specify a Probit regression model of the probability that a loan is secured when firm i takes a loan in year $t$. This specification helps us determine the impact of the variables of interest on whether the loan is covered by collateral: 


$$
\begin{array}{r}
\operatorname{Pr}\left(\text { Secured }_{i, t}=1\right)=\varnothing\left(\alpha_{0}+\alpha_{1} \text { PIIGS }_{i, t-1}+\alpha_{2} \text { Crisis }_{+}\right. \\
\alpha_{3} \text { PIIGS } S_{i, t-1} \text { Crisis }^{\prime} \\
\left.\beta^{\prime} Z_{i, t-1}+\gamma_{i}+\mu_{t}+\epsilon_{i, t}\right)
\end{array}
$$

\section{Data and Preliminary Analysis}

The bank loan contract data for our analysis comes from Reuters' Deal Scan database of large transnational bank loans. Almost all these loans are syndicated, i.e., either it is developed by investment or commercial banks. Then we match these loan data with lenders' accounting data from Bankscope database, borrowers' accounting data from Compustat global and Capital IQ databases and stock price data from Compustat global database. In this study, lenders include all commercial and investment banks and other financial institutions (SIC codes 6000 - 6999). In addition, borrowers include all companies from other industries. To control for fluctuation in the macroeconomic environment, we collect the term spread (it is the difference between the 10-year and 2-year US Treasury yield) and the credit spread (it is the difference between AAA and BAA corporate bond yield) from the World Bank ${ }^{3}$. We emphasis on the relationship between borrowers' origin and loan terms in the sample including only European lenders and borrowers (named "Europe sample").

Table 1

Variables Definition

This table provides variables definition used in this research

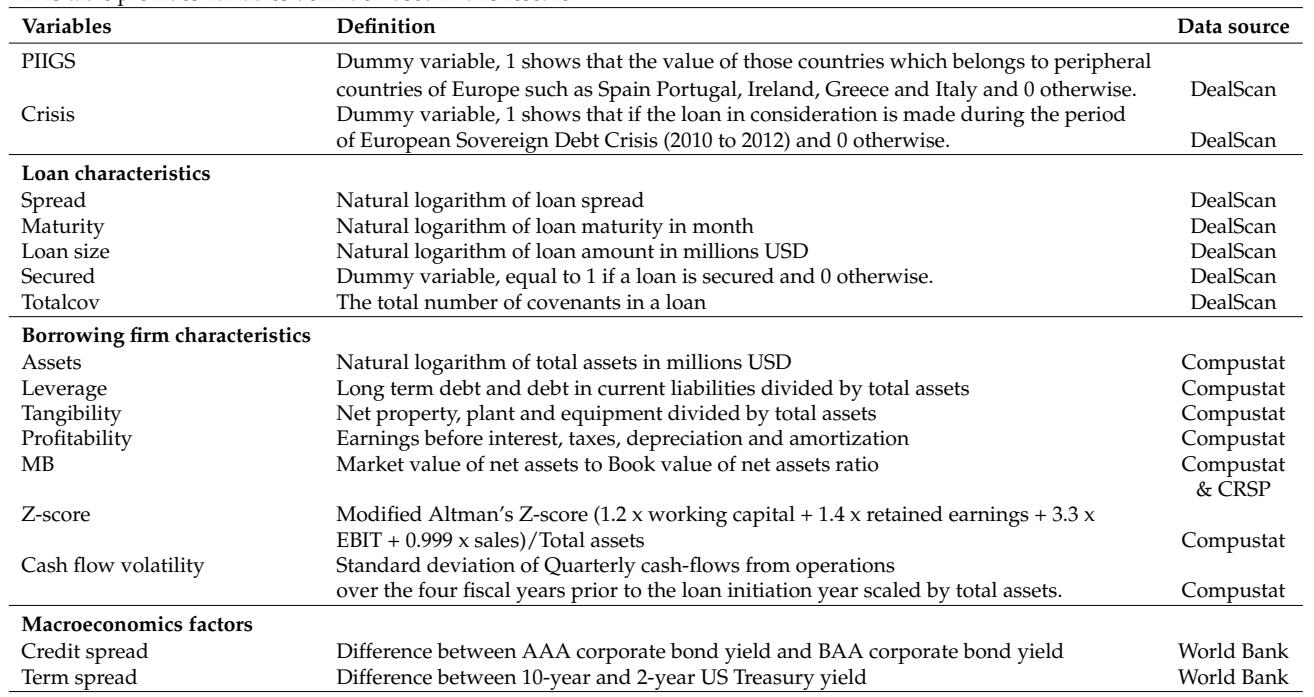

As a check for the robustness of the findings with this sample, we also see whether similar conclusions can be made with a sample include lenders and borrowers from all

\footnotetext{
${ }^{3}$ To account for bias in the results due to outliers, we opt for winsorizing all accounting data at the 1st and 99th percentiles in the subsequent analyses.
} 
countries (named "full sample"). As such, throughout the paper, parallel presentations of the results from both samples are conducted.

Table 1 presents the variables definition used and data source. All data collected are annual data. All loan characteristic variables definition is straightforward. Additionally, the dummy variable "secured" represents the cases where loans are covered by collateral.

\begin{tabular}{|c|c|c|c|c|c|}
\hline $\begin{array}{l}\text { Distribution of syndicated loa } \\
\text { This table presents the total n } \\
\text { and non-PIIGS countries in or } \\
\text { and (ii) the rest of the sample }\end{array}$ & $\begin{array}{l}\text { is } \\
\text { mber of } \\
\text { r sample } \\
\text { non-cris }\end{array}$ & $\begin{array}{l}\text { loans made by } \\
\text { in (i) the peri } \\
\text { s period). }\end{array}$ & $\begin{array}{l}\text { y banks whose headquarters are locat } \\
\text { od classified as the European Sovereig }\end{array}$ & $\begin{array}{l}\mathrm{d} \text { in PIIGS } \\
\mathrm{n} \text { Debt Cris }\end{array}$ & $\begin{array}{l}\text { untries } \\
(2010-2012)\end{array}$ \\
\hline A. PIIGS Countries & & & & & \\
\hline Borrower country & & Crisis & & Non-crisis & \\
\hline Portugal & & 6 & & 228 & \\
\hline Ireland & & 19 & & 560 & \\
\hline Italy & & 53 & & 1,147 & \\
\hline Greece & & 18 & & 103 & \\
\hline Spain & & 70 & & 961 & \\
\hline All PIIGS borrower countries & & 166 & & 2,999 & \\
\hline B. Other Countries & & & & & \\
\hline Borrower country & Crisis & Non-crisis & Borrower country & Crisis & Non-crisis \\
\hline Argentina & 0 & 32 & Netherlands & 83 & 1,067 \\
\hline Australia & 32 & 2,190 & New Zealand & 5 & 50 \\
\hline Austria & 17 & 43 & Norway & 51 & 1,091 \\
\hline Belgium & 41 & 312 & Pakistan & 0 & 3 \\
\hline Brazil & 12 & 152 & Peru & 0 & 9 \\
\hline Canada & 16 & 421 & Philippines & 2 & 235 \\
\hline Chile & 1 & 16 & Poland & 10 & 268 \\
\hline Colombia & 2 & 148 & Russia & 83 & 628 \\
\hline Czech Republic & 1 & 205 & Singapore & 7 & 246 \\
\hline Denmark & 15 & 694 & Slovakia & 0 & 229 \\
\hline Finland & 48 & 873 & South Africa & 17 & 212 \\
\hline France & 175 & 3,254 & South Korea & 25 & 840 \\
\hline Germany & 207 & 2,500 & Sri Lanka & 0 & 5 \\
\hline Hungary & 2 & 64 & Sweden & 61 & 980 \\
\hline India & 24 & 322 & Switzerland & 77 & 600 \\
\hline Indonesia & 7 & 69 & Taiwan & 0 & 31 \\
\hline Israel & 4 & 119 & Thailand & 3 & 35 \\
\hline Japan & 14 & 417 & Turkey & 99 & 392 \\
\hline Luxembourg & 25 & 98 & United Kingdom & 453 & 10,784 \\
\hline Malaysia & 4 & 225 & United States & 470 & 9,385 \\
\hline Mexico & 1 & 325 & Venezuela & 0 & 127 \\
\hline & & & All non PIIGS borrower countries & 2,094 & 39,696 \\
\hline
\end{tabular}

Table 2 shows the distribution of loans borrowed by PIIGS and non-PIIGS banks during crisis and non-crisis periods. We can see that the number of non-PIIGS loans clearly dominates that of PIIGS loans in our sample. Furthermore, the number of loans made during the ESDC is very small compared with those made during the rest of the sample. This could leads to potential selection biases and/or survivorship bias in our analyses.

Table 3 presents the descriptive statistics of the variables used in this paper. Note that these statistics are for the logarithm of the variables and need to be transformed for interpretation of the original units. With respect to the loan characteristics, the mean of natural logarithm of spread is 4.471 (or approximately 87.44 basis points (bsp)-0.87\%) and the range is quite wide, from $15 \mathrm{bsp}$ to $626 \mathrm{bsp}$. Similarly, the variation of loan size and maturity is also very large (from $\$ 1.378$ million to nearly $\$ 4,000$ million, and from 5 
months to as long as 144 months, respectively). The number of covenants also varies with a mean of 0.518 provisions across all loans. The loans with the most covenants get about 10 provisions in the contracts while there are loans that have a minimum of no covenant.

Table 3 is complemented by Table 4, which shows the means of the two sub-sample pairs (defined as in Table 2) for all lenders and borrowers and tests for their difference.

Table 3

Descriptive statistics of variables

This table presents the descriptive statistics of all the variables used in this research.

The sample period is from 1986 to 2015 . Table 1 provides the definition of these variables. 'Obs.' indicates the total number of annual observations for each variable.

\begin{tabular}{lcccccc}
\hline Variables & Obs. & Mean & Median & S.D & Maximum & Minimum \\
\hline Dummy variables & & & & & & \\
PIIGS & 44,955 & 0.024 & 0 & 0.154 & 1 & 0 \\
Crisis & 44,955 & 0.050 & 0 & 0.219 & 1 & 0 \\
\hline Loan characteristics & & & & & & \\
Spread & 25,087 & 4.471 & 4.605 & 1.039 & 6.440 & 2.708 \\
Maturity & 38,911 & 3.765 & 4.094 & 0.723 & 4.970 & 1.609 \\
Loan size & 44,910 & 4.956 & 4.961 & 1.616 & 8.294 & 0.321 \\
Performance & 44,955 & 0.099 & 0.000 & 0.298 & 1 & 0 \\
Secured & 44,955 & 0.197 & 0.000 & 0.397 & 1 & 0 \\
Totalcov & 44,955 & 0.518 & 0.000 & 1.614 & 10 & 0 \\
\hline Borrowing firm characteristics & & & & & & \\
Assets & 44,955 & 9.136 & 8.756 & 2.983 & 16.896 & 2.633 \\
Leverage & 42,807 & 0.361 & 0.341 & 0.207 & 1.1190 & 0 \\
Tangibility & 43,401 & 0.3 & 0.239 & 0.268 & 0.9150 & 0 \\
Profitability & 40,734 & 0.1 & 0.102 & 0.087 & 0.3660 & -0.241 \\
MB & 42,705 & 0.633 & 0.693 & 0.211 & 0.9700 & 0.1 \\
Z-score & 31,068 & 1.172 & 1.156 & 1.056 & 4.7080 & -2.742 \\
CF-volatility & 28,288 & 0.601 & 0.069 & 2.636 & 18.512 & 0.004 \\
\hline Macroeconomic factors & & & & & & \\
Credit spread & 44,896 & 0.870 & 0.810 & 0.298 & 3.38 & 0.55 \\
Term spread & 44,896 & 0.974 & 0.610 & 0.904 & 2.84 & -0.41 \\
\hline
\end{tabular}

As can be seen from panel A of this table, all of the loan characteristics for the non-PIIGS borrowers are significantly different from those for the PIIGS borrowers. Specifically, on average, relative to PIIGS borrowers, non-PIIGS borrowers receive higher loan spread, shorter maturity, smaller loan size and has a higher number of total covenants. These seemingly counter-intuitive observations are due to the fact that the full sample includes borrowers from countries all over the world, some of which have lower credit quality than PIIGS thus explains the overall less favorable loan terms. In terms of the characteristics of the borrowers, non-PIIGS firms tend to have less assets (smaller size), higher market-to-book ratio and higher Z-score (although the latter two differences are not economically important). Other variables, such as level of debt used (leverage), tangibility, profitability and cash flow volatility do not exhibit significant difference both in statistic and economic terms. Credit spread and term spread, our two macroeconomic indicators, although significantly different, are not economically different in the two sub-samples. Over all, it appears that the systematic risk in non-PIIGS countries is slightly less than that of the PIIGS countries.

Moving on to comparing crisis and non-crisis samples, panel B of Table 4 shows that the non-crisis period has generally looser loan terms: lower spread, lower maturity, 
smaller loan size, all of which exhibit statistically and economically importance. This is not the case for the total covenant number however. Interestingly, the results for comparing borrowing firm characteristics in these two sub-samples mirror that of the previous two sub-samples, indicating a linkage between borrowers from PIIGS countries and the crisis period. It appears that PIIGS countries tend to borrow more in time of crisis. Finally, across countries, credit spread and term spread are both significantly higher in crisis period, indicating the overall higher riskiness of the financial environment. In general, it can be concluded that when considering all borrowers in our sample, the differences between PIIGS and non-PIIGS and between crisis and non-crisis year have a thing in common: they are significantly different in terms of the loan characteristics but not very different in terms of the borrowing firms' characteristics. In other words, even though PIIGS borrowers exhibit no large difference relative to the rest of the borrowers (even in crisis time), the two country groups are treated very differently by lenders of these syndicated loans.

Table 5 presents the same measure of difference in means when considering lenders and borrowers from Europe only. Relative to the full sample used in Table 4, several changes appear. Panel A shows that the difference between non-PIIGS and PIIGS borrowers are very significant in our expected direction: non-PIIGS loans tend to be charged with lower spread, have longer maturity with larger size and greater number of debt covenants. Also expected, non-PIIGS borrowers are larger, have lower leverage and less tangible asset, lower market-to-book ratio and higher Z-score. There is no significant difference in terms of profitability and the volatility of cash flows. Overall, it can be concluded that non-PIIGS firms are more financially stable than their PIIGS counterparts.

The observations made when comparing non-crisis and crisis periods are similar to those made with Table 4: on average, loans during non-crisis years realized lower spread and lower size. Interestingly, the difference is much larger when compared with Table 4 , indicating that relative to the world standard, European banks adopt less prudential approach to European firms in this period. This helps explain the widespread impact of the ESDC in this region. Similar to Table 4, there is not much difference in firm characteristics between the two periods. For the macroeconomic environment indicators, both credit spread and term spread are larger in crisis period.

An overview of the correlation among the variables is helpful in our subsequent analyses. Table 6 shows that both the loan characteristics and firm characteristics variables exhibit substantial within-variable-group correlation. We can see this by looking and the clusters of highly significant values indicated by the matrix formed by rows (3)-(8) and columns (3)-(8). Similarly, the matrix formed by rows (9)-(15) and columns (9)-(15) also indicates high within group correlation.

\section{Empirical Results}

In this section, we formally test for the implications of the descriptive observations made in Section 4, as well as formally test for the hypotheses stated in Section 2 by using regressions (3.1) and its variations specified in Section 3. Table 7 presents the first regression results for the full sample. As can be seen, loan spread is specified to be determined by 


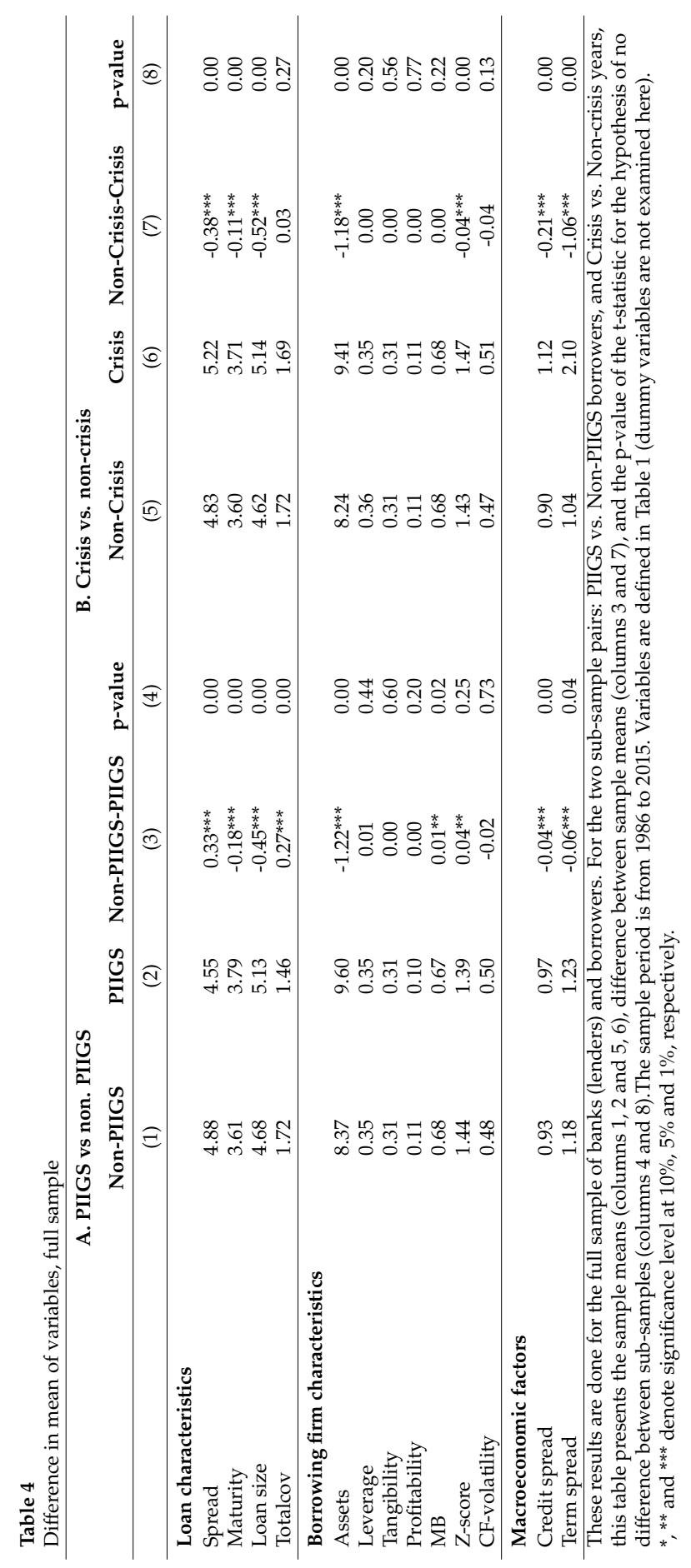


a one-period lag term of PIIGS dummy, a crisis period dummy and a vector of control variables. We use the lag of PIIGS since it takes time for bank to update their terms based on the performance of loans made for PIIGS borrowers. Except for the specification in column (1), we also control for firm industry, loan purpose and loan type fixed effects which all have significant impact on loan spread. We can see that in all of our specifications, the impact of the crisis dummy variable is very significant.

In particular, when we do not control for loan and firm characteristics, on average loans made during crisis period have a spread about 1.6 or exp(0.47) basis points (bsp) higher than that of non-crisis loans. After controlling for loan and borrower characteristics, the influence of crisis period slightly declines, resulting in a $1.5 \mathrm{bsp}$ difference. However, when we further control for macroeconomic conditions, the effect is reduced to only $1.23 \mathrm{bsp}$. Intuitively, including term spread and credit spread weakens the influence of the crisis dummy because loan spread is always positively dependent on these variables. We also observe a significant negative effect of the PIIGS dummy variable, which is persistent across specifications. This implies that PIIGS borrower tend to be charged lower spread, which is in accordance with the observation made in Table 4. Again it can be argued that some borrowers from countries in other regions may have worse bank-custormer relationships than PIIGS borrowers. However, it is remarkable that the effect of PIIGS apparently still worsens the negative impact of crisis period, as shown in the coefficient estimates of the interaction variable. Particularly, conditioned on the fact that the ESDC happened, loan made for PIIGS countries realized a spread larger than loan made for non-PIIGS by a very substantial range of 1.82 to $1.95 \mathrm{bsp}$.

Table 5

Difference in mean of variables, Europe sample

These results are done for the Europe sample of banks (lenders) and borrowers. For the two sub-sample pairs: PIIGS vs. Non-PIIGS borrowers, and Crisis vs. Non-crisis years, this table presents the sample means (columns 1, 2 and 5, 6), difference between sample means (columns 3 and 7), and the p-value of the t-statistic for the hypothesis of no difference between sub-samples (columns 4 and 8). The sample period is from 1986 to 2015. Variables are defined in table 1 (dummy variables are not examined here). ${ }^{*}, * *$ and ${ }^{* * *}$ denote significance level at $10 \%, 5 \%$ and $1 \%$, respectively.

\begin{tabular}{lcccccccc}
\hline & Non-PIIGS & PIIGS & Non-PIIGS-PIIGS & p-value & Non-Crisis & Crisis & Non-Crisis-Crisis & p-value \\
\hline & $(1)$ & $(2)$ & $(3)$ & $(4)$ & $(5)$ & $(6)$ & $(7)$ & $(8)$ \\
\hline Loan characteristics & & & & & & & & \\
Spread & 4.46 & 4.75 & $-0.29^{* * *}$ & 0.00 & 4.42 & 5.31 & $-0.89^{* * *}$ & 0.00 \\
Maturity & 3.78 & 3.41 & $0.37^{* * *}$ & 0.00 & 3.76 & 3.79 & -0.02 & 0.15 \\
Loan size & 4.96 & 4.75 & $0.21^{* * *}$ & 0.00 & 4.92 & 5.60 & $-0.68^{* * *}$ & 0.00 \\
Totalcov & 0.82 & 0.10 & $0.72^{* * *}$ & 0.00 & 0.80 & 0.74 & 0.06 & 0.13 \\
\hline Borrower characteristics & & & & & & & & \\
Assets & 9.17 & 7.85 & $1.32^{* * *}$ & 0.00 & 9.15 & 8.91 & $0.23^{* * *}$ & 0.00 \\
Leverage & 0.33 & 0.37 & $-0.04^{* * *}$ & 0.00 & 0.33 & 0.33 & 0.00 & 0.39 \\
Tangibility & 0.26 & 0.37 & $-0.10^{* * *}$ & 0.00 & 0.26 & 0.26 & 0.01 & 0.19 \\
Profitability & 0.10 & 0.10 & 0.00 & 0.62 & 0.10 & 0.10 & 0.00 & 0.69 \\
MB & 0.61 & 0.73 & $-0.13^{* * *}$ & 0.00 & 0.61 & 0.61 & 0.00 & 0.62 \\
Z-score & 1.27 & 0.86 & $0.41^{* * *}$ & 0.00 & 1.25 & 1.33 & $-0.08^{* * *}$ & 0.00 \\
CF-volatility & 0.58 & 0.51 & 0.07 & 0.53 & 0.59 & 0.49 & 0.09 & 0.19 \\
\hline Macroeconomic factors & & & & & & & & \\
Credit spread & 0.87 & 0.96 & $-0.09^{* * *}$ & 0.00 & 0.86 & 1.10 & $-0.24^{* * *}$ & 0.00 \\
Term spread & 0.98 & 0.87 & $0.11^{* * *}$ & 0.00 & 0.91 & 2.13 & $-1.22^{* * *}$ & 0.00 \\
\hline
\end{tabular}




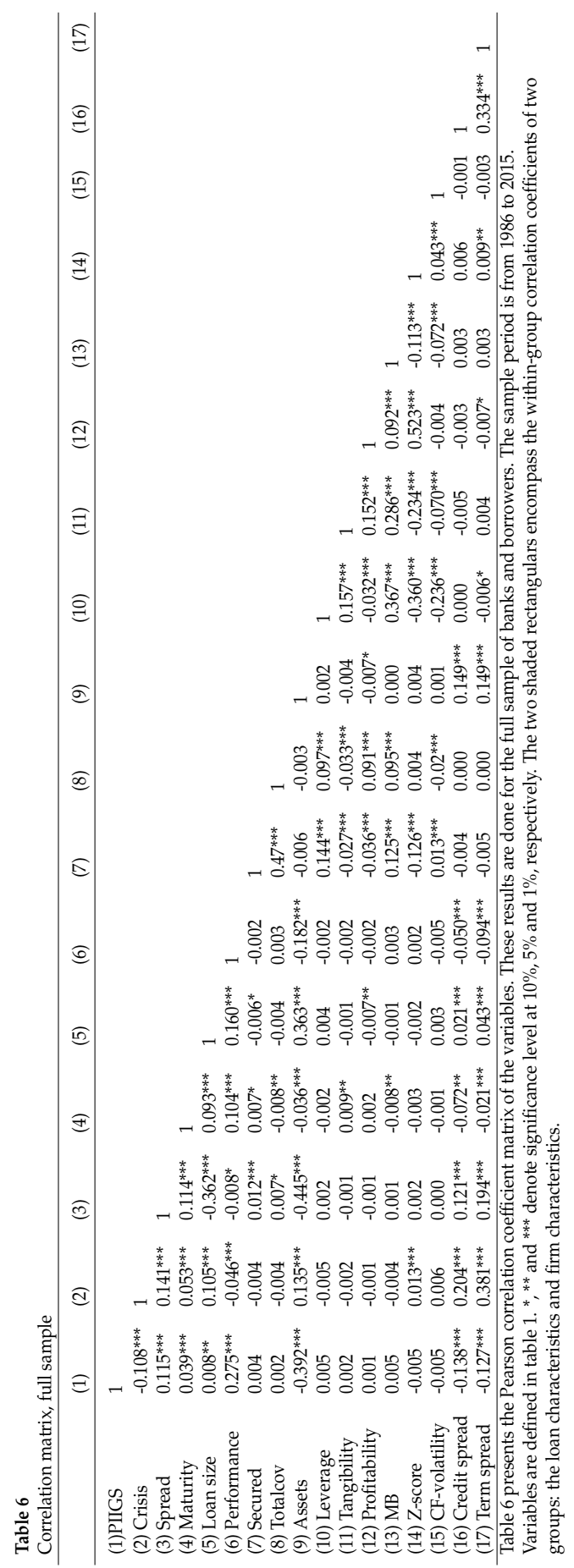


Table 7

Correlation matrix, Full sample

\begin{tabular}{|c|c|c|c|c|c|}
\hline & (1) & (2) & (3) & (4) & (5) \\
\hline \multirow[t]{2}{*}{ Constant } & $5.1333^{* * *}$ & $4.6869^{* * *}$ & $4.7511^{* * *}$ & $4.7431^{* * *}$ & $4.4637^{* * *}$ \\
\hline & -46.780 & -37.480 & -35.410 & -33.380 & -34.990 \\
\hline \multirow{2}{*}{ PIIGS $_{i, t 1}$} & $-0.6571^{* * *}$ & $-0.6951^{* * *}$ & $-0.7252^{* * *}$ & $-0.7441^{* * *}$ & $-0.8560^{* * *}$ \\
\hline & $(-3.7800)$ & $(-3.8500)$ & $(-3.7900)$ & $(-3.7600)$ & $(-4.8100)$ \\
\hline \multirow[t]{2}{*}{ Crisis } & $0.4685^{* * *}$ & $0.4106^{* * *}$ & $0.4058^{* * *}$ & $0.4057^{* * *}$ & $0.2177^{* * *}$ \\
\hline & -33.220 & -33.360 & -29.330 & -28.840 & -15.280 \\
\hline \multirow{2}{*}{ PIIGS $_{i, t 1} \times$ crisis } & $0.6789^{* * *}$ & $0.5930^{* * *}$ & $0.6071^{* * *}$ & $0.6164^{* * *}$ & $0.6464^{* * *}$ \\
\hline & -6.2300 & -6.1100 & -6.0800 & -5.8500 & -6.4400 \\
\hline \multirow[t]{2}{*}{ Assets } & & & -0.0027 & 0.0006 & 0.0002 \\
\hline & & & $(-1.4100)$ & -0.2500 & -0.0900 \\
\hline \multirow{2}{*}{ Leverage } & & & 0.0187 & 0.0013 & 0.0048 \\
\hline & & & -0.7800 & -0.0500 & -0.1900 \\
\hline \multirow[t]{2}{*}{ Tangibility } & & & 0.0093 & 0.0136 & 0.0149 \\
\hline & & & -0.4300 & -0.6000 & -0.6700 \\
\hline \multirow[t]{2}{*}{ Profitability } & & & 0.0119 & 0.0147 & 0.0470 \\
\hline & & & -0.1800 & -0.2100 & -0.6800 \\
\hline \multirow[t]{2}{*}{ MB } & & & 0.0091 & 0.0086 & 0.0054 \\
\hline & & & -0.3000 & -0.2700 & -0.1800 \\
\hline \multirow[t]{2}{*}{ Z-Score } & & & 0.0041 & 0.0041 & 0.0031 \\
\hline & & & -0.8900 & -0.8500 & -0.6600 \\
\hline \multirow[t]{2}{*}{ CF-volatility } & & & 0.0023 & $0.0030^{*}$ & $0.0034^{*}$ \\
\hline & & & -1.3300 & -1.6800 & -1.9300 \\
\hline \multirow[t]{2}{*}{ Maturity } & & & & 0.0028 & 0.0037 \\
\hline & & & & -0.4300 & -0.5600 \\
\hline \multirow[t]{2}{*}{ Loan size } & & & & -0.0032 & -0.0040 \\
\hline & & & & $(-0.9900)$ & $(-1.2500)$ \\
\hline \multirow[t]{2}{*}{ Performance } & & & & -0.0069 & -0.0087 \\
\hline & & & & $(-0.4800)$ & $(-0.6200)$ \\
\hline \multirow{2}{*}{ Secured } & & & & $0.0242^{*}$ & $0.0254^{* *}$ \\
\hline & & & & -1.8700 & -2.0000 \\
\hline \multirow[t]{2}{*}{ Totalcov } & & & & 0.0016 & 0.0019 \\
\hline & & & & -0.6800 & -0.8200 \\
\hline \multirow[t]{2}{*}{ Creditspread } & & & & & $0.2360^{* * *}$ \\
\hline & & & & & -14.990 \\
\hline \multirow{2}{*}{ Termspread } & & & & & $0.1439^{* * *}$ \\
\hline & & & & & -20.550 \\
\hline Borrower industry fixed effect & Yes & Yes & Yes & Yes & Yes \\
\hline Loan purpose & No & Yes & Yes & Yes & Yes \\
\hline Loan type & No & Yes & Yes & Yes & Yes \\
\hline Obs. & 53,810 & 53,810 & 36,281 & 33,991 & 33,513 \\
\hline Adjusted R2 & 0.0937 & 0.3398 & 0.3379 & 0.3371 & 0.3713 \\
\hline
\end{tabular}

This table presents the results of the following panel regression:

$$
\begin{aligned}
& \text { Spread }_{i, t}=\alpha_{0}+\alpha_{1} \text { PIIGS }_{i, t-1}+\alpha_{2} \text { Crisis }+\alpha_{3} \text { PIIGS }_{i, t-1} \text { Crisis } \\
& +\beta^{\prime} Z_{i, t-1}+\gamma_{i}+\mu_{t}+\epsilon_{i, t}
\end{aligned}
$$

In which, the dependent variable Spread $_{i, t}$ is the natural logarithm of bank loan spread for loan i in year t; PIIGS is a dummy variable which equals to 1 if the borrower is located in the group of peripheral countries: Portugal, Ireland, Italy, Greece, and Spain and 0 otherwise; Crisis is a dummy variable which equals to 1 if the loan in consideration is made during the period of European Sovereign Debt Crisis (2010 to 2012) and 0 otherwise. $Z_{i, t-1}$ is a vector of control variables for firm $i$ in year $\mathrm{t}-1 . \gamma_{i}$ and $\mu_{t}$ represent the 
fixed effect of industry and year, respectively. In all specifications, the t-statistics reported are based on heteroscedasticity- and sample clustering at firm level-robust standard errors (White, 1980; Petersen, 2009). The sample period is 1986-2015. The sample includes all lenders and borrowers. All the variables are defined in Table $1 .{ }^{*},{ }^{* *}$ and ${ }^{* * *}$ denote the significance level of $10 \%, 5 \%$ and $1 \%$, respectively.

Moving on to the sample of European borrowers and lenders, in Table 8 we observe a similar pattern. The effect of the ESDC is stronger here, increasing loan spread by a range of 1.44 to $2.16 \mathrm{bsp}$. Being a PIIGS borrower significantly increases the spread during crisis, in exceed of $1 \mathrm{bsp}$. It appears that relative to other regions, European lenders may have better assessment or information regarding the performance of these intra-regional loans. A clear point from the above analyses it can be seen that even though its coefficient is less significant, PIIGS borrower are always charged lower spread on average (during both crisis and non-crisis time). This shows how abnormal the negative effect of the Europe crisis is, which severely and abruptly weakens the credit rating of these peripheral countries.

Table 8 presents the results of the following panel regression:

$$
\begin{aligned}
& \text { Spread }_{i, t}=\alpha_{0}+\alpha_{1} \text { PIIGS } S_{i, t-1}+\alpha_{2} \text { Crisis }+\alpha_{3} \text { PIIGS } S_{i, t-1} \text { Crisis }+ \\
& \beta^{\prime} Z_{i, t-1}+\gamma_{i}+\mu_{t}+\epsilon_{i, t}
\end{aligned}
$$

In which, the dependent variable Spreadi,t is the natural logarithm of bank loan spread for loan i in year t; PIIGS is a dummy variable which equals to 1 if the borrower is located in the group of peripheral countries: Portugal, Ireland, Italy, Greece, and Spain and 0 otherwise; Crisis is a dummy variable which equals to 1 if the loan in consideration is made during the period of European Sovereign Debt Crisis (2010 to 2012) and 0 otherwise. $Z_{i, t-1}$ is a vector of control variables for firm i in year $\mathrm{t}-1 . \gamma_{i}$ and $\mu_{t}$ represent the fixed effects of industry and year, respectively. In all specifications, the t-statistics reported are based on heteroskedasticity and sample clustering at firm level - robust standard errors (White, 1980; Petersen, 2009). The sample period is 1986-2015. The sample includes only European lenders and borrowers. Variables are defined in Table $1 .{ }^{*},{ }^{* *}$ and ${ }^{* * *}$ denote the significance level of $10 \%, 5 \%$ and $1 \%$, respectively.

Next, we examine the impact of these dummies on other loan terms. In the first three columns of Table 9, we use different loan term variables as our dependent variable: total number of covenants of loan contract, the natural logarithm of loan maturity in month and the natural logarithm of the amount of loan in millions USD. Additionally, to capture unobserved causal links between these variables, they are also used as explanatory variables whenever they are not dependent variables. We can see that PIIGS borrowers generally receive less loan covenants, enjoy longer maturity and have larger loan size. The impact of crisis period to these variables is also significantly positive. However their interaction does not have any significant impact. It seems that firms from the peripheral countries still enjoy favorable terms from all lenders, possibly because of their status as being backed up by the European Central Bank. 
Table 8

Impact of PIIGS borrowers on bank loan spread, Europe sample

\begin{tabular}{|c|c|c|c|c|c|}
\hline & (1) & (2) & (3) & (4) & (5) \\
\hline \multirow[t]{2}{*}{ Constant } & $4.0068^{* * *}$ & $4.9821^{* * *}$ & $4.4288^{* * *}$ & $4.1063^{* * *}$ & $4.0078^{* * *}$ \\
\hline & -26.270 & -18.000 & -18.360 & -14.830 & -13.930 \\
\hline \multirow{2}{*}{ PIIGS $_{i, t 1}$} & 0.1561 & 0.1015 & $-0.4462^{* *}$ & $-0.5636^{* * *}$ & $-0.4867^{* *}$ \\
\hline & -0.6400 & -0.3300 & $(-2.5300)$ & $(-2.8700)$ & $(-2.4300)$ \\
\hline \multirow[t]{2}{*}{ Crisis } & $0.7769^{* * *}$ & $0.6933^{* * *}$ & $0.6221^{* * *}$ & $0.6385^{* * *}$ & $0.3711^{* * *}$ \\
\hline & -10.910 & -10.200 & -7.8800 & -7.6200 & -3.7700 \\
\hline \multirow{2}{*}{ PIIGS $_{i, t 1} \times$ crisis } & $0.5450^{*}$ & 0.4549 & $1.0444^{* * *}$ & $1.1659^{* * *}$ & $0.9600^{* * *}$ \\
\hline & -1.7400 & -1.2900 & -4.0100 & -4.3800 & -3.5200 \\
\hline \multirow[t]{2}{*}{ Assets } & & & 0.0211 & 0.0194 & 0.0193 \\
\hline & & & -1.0600 & -0.8900 & -0.900 \\
\hline \multirow[t]{2}{*}{ Leverage } & & & $0.9900^{* * *}$ & $0.9012^{* * *}$ & $0.7235^{* * *}$ \\
\hline & & & -3.9700 & -3.3400 & -2.7300 \\
\hline \multirow[t]{2}{*}{ Tangibility } & & & 0.3474 & 0.3871 & 0.2693 \\
\hline & & & -1.5700 & -1.5500 & -1.1600 \\
\hline \multirow[t]{2}{*}{ Profitability } & & & $-1.3289^{*}$ & $-1.4088^{* *}$ & $-1.3353^{* *}$ \\
\hline & & & $(-1.9300)$ & $(-2.0700)$ & $(-1.9900)$ \\
\hline \multirow[t]{2}{*}{ MB } & & & -0.0892 & -0.1741 & -0.0871 \\
\hline & & & $(-0.2300)$ & $(-0.4400)$ & $(-0.2200)$ \\
\hline \multirow[t]{2}{*}{ Z-Score } & & & $0.1796^{* * *}$ & $0.1943^{* * *}$ & $0.1682^{* * *}$ \\
\hline & & & -2.7200 & -2.8600 & -2.6700 \\
\hline \multirow[t]{2}{*}{ CF-volatility } & & & $0.0232^{* * *}$ & 0.0098 & -0.0018 \\
\hline & & & -2.9000 & -1.2700 & $(-0.2100)$ \\
\hline \multirow[t]{2}{*}{ Maturity } & & & & -0.0116 & -0.0021 \\
\hline & & & & $(-0.1200)$ & $(-0.0200)$ \\
\hline \multirow[t]{2}{*}{ Loan size } & & & & 0.0065 & 0.0046 \\
\hline & & & & -0.1700 & -0.1200 \\
\hline \multirow[t]{2}{*}{ Performance } & & & & -0.0476 & -0.0261 \\
\hline & & & & $(-0.2900)$ & $(-0.1600)$ \\
\hline \multirow[t]{2}{*}{ Secured } & & & & 0.2126 & $0.2154^{*}$ \\
\hline & & & & -1.6400 & -1.6800 \\
\hline \multirow[t]{2}{*}{ Totalcov } & & & & -0.0018 & 0.0002 \\
\hline & & & & $(-0.0700)$ & -0.0100 \\
\hline \multirow[t]{2}{*}{ Credit spread } & & & & & 0.0535 \\
\hline & & & & & -0.3900 \\
\hline \multirow{2}{*}{ Term spread } & & & & & $0.2347^{* * *}$ \\
\hline & & & & & -4.1900 \\
\hline Borrower industry fixed effect & Yes & Yes & Yes & Yes & Yes \\
\hline Loan purpose & No & Yes & Yes & Yes & Yes \\
\hline Loan type & No & Yes & Yes & Yes & Yes \\
\hline Obs. & 25,087 & 25,087 & 15,370 & 13,908 & 13,879 \\
\hline Adjusted R2 & 0.2862 & 0.5157 & 0.5526 & 0.5524 & 0.5780 \\
\hline
\end{tabular}

This also shows how banks in crisis tend to adopt imprudent approaches to their lending business, all of which contributes to worsen the upcoming fiasco. The fourth column of Table 9 adopts a Probit model of the probability that a loan is secured when firm i takes a loan in year it. It shows that both PIIGS and crisis dummy have a very significant and positive impact on whether the loan is secured. In other words, banks adopt stricter rules for troubled borrowers and during crisis time. However, their interaction does not have any significant impact. 
Table 9

Impact of PIIGS borrowers on loan terms, Full sample

\begin{tabular}{|c|c|c|c|c|}
\hline & OLS regression & & & Probit regression \\
\hline & Total cov & Maturity & Loansize & Secured \\
\hline & (1) & (2) & (3) & (4) \\
\hline \multirow[t]{2}{*}{ Constant } & $0.9631^{* * *}$ & $2.3501^{* * *}$ & $5.5111^{* * *}$ & $-2.6824^{* * *}$ \\
\hline & -5.2400 & -23.850 & -42.300 & $(-9.3800)$ \\
\hline \multirow{2}{*}{ PIIGS $_{i, t 1}$} & $-0.6807^{* * *}$ & $0.4474^{* * *}$ & $0.7468^{* * *}$ & $0.9216^{* * *}$ \\
\hline & $(-4.0100)$ & -4.3200 & -3.5300 & -2.8800 \\
\hline \multirow[t]{2}{*}{ Crisis } & $0.0823^{* *}$ & $0.0857^{* * *}$ & $0.4661^{* * *}$ & $-0.0512^{*}$ \\
\hline & -2.1600 & -9.2100 & -17.4300 & $(-1.7400)$ \\
\hline \multirow{2}{*}{ PIIGS $_{i, t 1} \times$ crisis } & 0.0913 & -0.0966 & $-0.3828^{*}$ & -0.0007 \\
\hline & -0.3900 & $(-1.5800)$ & $(-1.8900)$ & $(-0.0000)$ \\
\hline \multirow[t]{2}{*}{ Assets } & -0.0025 & -0.0008 & -0.0028 & 0.0036 \\
\hline & $(-0.4600)$ & $(-0.6100)$ & $(-0.6700)$ & -0.8800 \\
\hline \multirow[t]{2}{*}{ Leverage } & 0.0868 & $-0.0319 *$ & 0.0477 & -0.0164 \\
\hline & -1.3200 & $(-1.8900)$ & -0.9700 & $(-0.3300)$ \\
\hline \multirow[t]{2}{*}{ Tangibility } & -0.0159 & $0.0246^{*}$ & -0.0018 & $0.0903^{* *}$ \\
\hline & $(-0.3000)$ & -1.9300 & $(-0.0400)$ & -2.3200 \\
\hline \multirow{2}{*}{ Profitability } & -0.1352 & 0.0253 & $-0.2345^{*}$ & -0.0484 \\
\hline & $(-0.7800)$ & -0.5700 & $(-1.7800)$ & $(-0.4100)$ \\
\hline \multirow[t]{2}{*}{ MB } & 0.0835 & -0.0236 & 0.0186 & 0.0572 \\
\hline & -0.9100 & $(-1.2600)$ & -0.3100 & -0.8300 \\
\hline \multirow[t]{2}{*}{ Z-Score } & $0.0263^{* *}$ & -0.004 & -0.0013 & 0.0146 \\
\hline & -2.0200 & $(-1.2800)$ & $(-0.1400)$ & -1.6300 \\
\hline \multirow[t]{2}{*}{ CF-volatility } & -0.0009 & -0.0015 & 0.0010 & 0.0011 \\
\hline & $(-0.2000)$ & $(-1.3500)$ & -0.3300 & -0.3600 \\
\hline \multirow[t]{2}{*}{ Maturity } & 0.0015 & & -0.0159 & 0.0081 \\
\hline & -0.0900 & & $(-1.1700)$ & -0.6700 \\
\hline \multirow[t]{2}{*}{ Loan size } & $-0.0139 *$ & -0.0006 & & -0.0043 \\
\hline & $(-1.6600)$ & $(-0.3000)$ & & $(-0.7200)$ \\
\hline \multirow[t]{2}{*}{ Performance } & 0.0069 & -0.0117 & 0.0062 & -0.0181 \\
\hline & -0.2300 & $(-1.2300)$ & -0.2500 & $(-0.6800)$ \\
\hline \multirow[t]{2}{*}{ Secured } & -0.0218 & $0.0125^{*}$ & $-0.0447^{*}$ & \\
\hline & $(-0.7300)$ & -1.7300 & $(-1.6600)$ & \\
\hline \multirow[t]{2}{*}{ Totalcov } & & -0.0011 & 0.0011 & $0.0090^{* *}$ \\
\hline & & $(-0.7000)$ & -0.2400 & -2.2100 \\
\hline \multirow[t]{2}{*}{ Creditspread } & $0.1289^{* * *}$ & $-0.0895^{* * *}$ & $0.1135^{* * *}$ & 0.0349 \\
\hline & -3.4200 & $(-9.1500)$ & -4.300 & -1.1700 \\
\hline \multirow[t]{2}{*}{ Termspread } & $-0.0409^{* *}$ & $-0.0167^{* * *}$ & $0.0240^{*}$ & $0.0556^{* * *}$ \\
\hline & $(-2.2000)$ & $(-4.2200)$ & -1.7800 & -4.3100 \\
\hline Borrower industry fixed effect & Yes & Yes & Yes & Yes \\
\hline Loan purpose & Yes & Yes & Yes & Yes \\
\hline Loan type & Yes & Yes & Yes & Yes \\
\hline Obs. & 50,211 & 49,926 & 50,202 & 49,955 \\
\hline Adjusted R2/Pseudo R2 & 0.3284 & 0.4879 & 0.2094 & 0.2910 \\
\hline
\end{tabular}

Table 9 presents the results of panel regression of PIIGS borrowers on loan term. Specifications (1) to (3) use the equation:

$$
\begin{array}{r}
Y_{i, t}=\alpha_{0}+\alpha_{1} \text { PIIGS }_{i, t-1}+\alpha_{2} \text { Crisis }+\alpha_{3} \text { PIIGS }_{i, t-1} \text { Crisis }+ \\
\beta^{\prime} Z_{i, t-1}+\gamma_{i}+\mu_{t}+\epsilon_{i, t}
\end{array}
$$

In which, the dependent variables, $Y_{i, t}$ are different terms of a bank loan for firm $\mathrm{i}$ in year $\mathrm{t}$, including Totalcov (the total number of covenants of loan contract), Maturity (the natural logarithm of loan maturity in month), Loansize (the natural logarithm of the 
amount of loan in millions USD). Specification (4) follows a Probit regression model of the probability that a loan is secured when firm $i$ takes a loan in year $t$ :

$$
\begin{array}{r}
\operatorname{Pr}\left(\text { Secured }_{i, t}=1\right)=\varnothing\left(\alpha_{0}+\alpha_{1} \text { PIIGS }_{i, t-1}+\alpha_{2} \text { Crisis }+\alpha_{3} \text { PIIG }_{i, t-1}\right. \\
\text { Crisis } \left.+\beta^{\prime} Z_{i, t-1}+\gamma_{i}+\mu_{t}+\epsilon_{i, t}\right)
\end{array}
$$

In both equations, PIIGS is a dummy variable which equals to 1 if the borrower is located in the group of peripheral countries: Portugal, Ireland, Italy, Greece, and Spain (PIIGS) and 0 otherwise; Crisis is a dummy variable which equals to 1 if the loan in consideration is made during the period of European Sovereign Debt Crisis (2010 to 2012) and 0 otherwise. $Z_{i, t-1}$ is a vector of control variables for firm i in year $\mathrm{t}-1$. $\gamma \mathrm{i}$ and $\mu \mathrm{t}$ represent the fixed effect of industry and year, respectively. In all specifications, the $t-$ statistics and z-statistics reported are based on heteroskedasticity and sample clustering at firm level-robust standard errors (White, 1980; Petersen, 2009). The sample period is 1996-2014. The sample includes all lenders and borrowers. All the variables are defined in Table 1 . $^{*}{ }^{* *}$ and ${ }^{* * *}$ denote the significance level of $10 \%, 5 \%$ and $1 \%$, respectively.

Table 10 presents the same set of results for the European sample. In the first three specifications, the impact of PIIGS, crisis and the interaction all have reduced significance. Again this shows the imprudent approach banks took during this perilous time, and it is worsen among European banks when dealing with PIIGS borrowers. From the fourth column, it can be seen that not only PIIGS but also the crisis dummy has significant positive impact on the probability of a secured loan. It appears that the status of the troubled countries during crisis is taken as a sign of risk that needs to be covered by collaterals. All in all, during the crisis period and from the perspective of PIIGS countries, the only loan term variable that became stricter is loan spread, the corresponding impact on other loan term variables are not as clear.

This table presents the results of panel regression of PIIGS borrowers on loan terms. Specifications (1) to (3) use the equation:

$$
\begin{aligned}
& Y_{i, t}=\alpha_{0}+\alpha_{1} P I I G S_{i, t-1}+\alpha_{2} \text { Crisis }+\alpha_{3} \text { PIIGS } S_{i, t-1} \text { Crisis }+ \\
& \beta^{\prime} Z_{i, t-1}+\gamma_{i}+\mu_{t}+\epsilon_{i, t}
\end{aligned}
$$

In which, the dependent variables, $Y_{i, t}$ are the different terms of a bank loan for firm $i$ in year $t$, including Totalcov (the total number of covenants of loan contract), Maturity (the natural logarithm of loan maturity in month), Loansize (the natural logarithm of the amount of loan in millions USD). 
Table 10

Impact of PIIGS borrowers on loan term, Europe sample

\begin{tabular}{|c|c|c|c|c|}
\hline & \multicolumn{3}{|l|}{ OLS regression } & \multirow{2}{*}{$\begin{array}{c}\text { Probit regression } \\
\text { Secured }\end{array}$} \\
\hline & Total Cov & Maturity & Loan size & \\
\hline & (1) & (2) & (3) & (4) \\
\hline \multirow[t]{2}{*}{ Constant } & $1.4701^{*}$ & $2.7086^{* * *}$ & $5.4162^{* * *}$ & -0.7205 \\
\hline & -1.8900 & -10.760 & -8.2100 & $(-1.0100)$ \\
\hline \multirow{2}{*}{ PIIGS $_{i, t 1}$} & 0.5629 & $0.2280^{* *}$ & $0.7075^{*}$ & $0.8665^{* * *}$ \\
\hline & -0.9800 & -2.1500 & -1.8300 & -3.0400 \\
\hline \multirow[t]{2}{*}{ Crisis } & $0.2292^{*}$ & 0.0004 & $0.5400^{* * *}$ & $0.4591^{* * *}$ \\
\hline & -1.8600 & -0.0100 & -4.8700 & -3.600 \\
\hline \multirow[t]{2}{*}{ PIIGS $_{i, t 1} \times$ crisis } & -0.4891 & -0.1038 & $-1.2852^{* *}$ & -0.3728 \\
\hline & $(-0.8700)$ & $(-0.6100)$ & $(-2.2800)$ & $(-0.5500)$ \\
\hline \multirow[t]{2}{*}{ Assets } & -0.0128 & $-0.0267^{*}$ & -0.0171 & 0.0031 \\
\hline & $(-0.4200)$ & $(-1.8000)$ & $(-0.6100)$ & -0.1000 \\
\hline \multirow[t]{2}{*}{ Leverage } & 0.0257 & -0.0986 & -0.4862 & $0.7586^{* *}$ \\
\hline & -0.0800 & $(-0.6100)$ & $(-1.5200)$ & -2.1000 \\
\hline \multirow[t]{2}{*}{ Tangibility } & -0.1251 & -0.1355 & 0.0660 & 0.3102 \\
\hline & $(-0.5200)$ & $(-1.2000)$ & -0.2100 & -0.7600 \\
\hline \multirow[t]{2}{*}{ Profitability } & 0.6738 & -0.5990 & -0.5406 & $-2.7862^{* *}$ \\
\hline & -0.6800 & $(-1.3200)$ & $(-0.5800)$ & $(-2.3600)$ \\
\hline \multirow[t]{2}{*}{ MB } & -0.6981 & 0.1302 & 0.1033 & $-2.4503^{* * *}$ \\
\hline & $(-1.4500)$ & -0.700 & -0.1800 & $(-3.5100)$ \\
\hline \multirow[t]{2}{*}{ Z-Score } & -0.0689 & 0.0566 & 0.0603 & 0.0851 \\
\hline & $(-0.8900)$ & -1.3000 & -0.7800 & -0.8700 \\
\hline \multirow[t]{2}{*}{ CF-volatility } & 0.0276 & -0.0141 & -0.0104 & $-0.0302^{*}$ \\
\hline & -1.0700 & $(-1.2200)$ & $(-0.6000)$ & $(-1.9600)$ \\
\hline \multirow[t]{2}{*}{ Maturity } & -0.1187 & & 0.0956 & 0.095 \\
\hline & $(-1.1500)$ & & -0.8300 & -0.9100 \\
\hline \multirow[t]{2}{*}{ Loan size } & 0.043 & 0.0159 & & 0.0277 \\
\hline & -1.0000 & -0.8000 & & -0.5600 \\
\hline \multirow[t]{2}{*}{ Performance } & -0.0438 & 0.0446 & $0.6655^{* * *}$ & -0.1058 \\
\hline & $(-0.3200)$ & -0.7400 & -3.7300 & $(-0.4300)$ \\
\hline \multirow[t]{2}{*}{ Secured } & -0.0054 & -0.0133 & 0.0387 & \\
\hline & $(-0.0300)$ & $(-0.2400)$ & -0.2800 & \\
\hline \multirow[t]{2}{*}{ Totalcov } & & 0.0082 & -0.0036 & 0.0378 \\
\hline & & -0.6400 & $(-0.1000)$ & -0.800 \\
\hline \multirow[t]{2}{*}{ Credit spread } & $0.3925^{* *}$ & $-0.1631^{* * *}$ & $0.2763^{* *}$ & -0.0068 \\
\hline & -2.0800 & $(-2.9100)$ & -2.0300 & $(-0.0400)$ \\
\hline \multirow[t]{2}{*}{ Term spread } & $0.1246^{*}$ & 0 & $-0.1301^{*}$ & $0.2670^{* * *}$ \\
\hline & -1.6600 & $(-0.0000)$ & $(-1.8300)$ & -3.5600 \\
\hline Borrower industry fixed effect & Yes & Yes & Yes & Yes \\
\hline Loan purpose & Yes & Yes & Yes & Yes \\
\hline Loan type & Yes & Yes & Yes & Yes \\
\hline Obs. & 25,599 & 24,127 & 25,621 & 23,824 \\
\hline Adjusted R2/Pseudo R2 & 0.3392 & 0.5920 & 0.4848 & 0.5244 \\
\hline
\end{tabular}

Specification (4) follows a Probit regression model of the probability that a loan is secured when firm $\mathrm{i}$ takes a loan in year $\mathrm{t}$ :

$$
\begin{array}{r}
\operatorname{Pr}\left(\text { Secured }_{i, t}=1\right)=\varnothing\left(\alpha_{0}+\alpha_{1} \text { PIIGS }_{i, t-1}+\alpha_{2} \text { Crisis }+\alpha_{3} \text { PIIGS }_{i, t-1}\right. \\
\text { Crisis } \left.+\beta^{\prime} Z_{i, t-1}+\gamma_{i}+\mu_{t}+\epsilon_{i, t}\right)
\end{array}
$$

In both equations, PIIGS is a dummy variable which equals to 1 if the borrower is located in the group of peripheral countries: Portugal, Ireland, Italy, Greece, and Spain (PIIGS) and 0 otherwise; Crisis is a dummy variable which equals to 1 if the loan in consideration is made during the period of European Sovereign Debt Crisis (2010 to 2012) and 
0 otherwise. $Z_{i, t-1}$ is a vector of control variables for firm i in year $\mathrm{t}-1 . \gamma_{i}$ and $\mu_{t}$ represent the fixed effect of industry and year, respectively. In all specifications, the t-statistics and z-statistics reported are based on heteroskedasticity- and sample clustering at firm levelrobust standard errors (White, 1980; Petersen, 2009). The sample period is 1996-2014. The sample includes only lenders and borrowers from Europe. All variables are defined in Table $1 .{ }^{*}{ }^{* *}$ and ${ }^{* * *}$ denote the significance level of $10 \%, 5 \%$ and $1 \%$, respectively.

\section{Conclusion}

We present robust evidence that during the European Sovereign Debt Crisis, banks tend to restrict loan terms (lower spreads, shorter maturity, more covenants and collateral required). The restriction seems to be amplified for borrowers from peripheral countries (Portugal, Ireland, Italy, Greece, and Spain) whose creditworthiness may be severely reduced in crisis. This result is consistent in both the full sample including all borrower countries and the sample with only European borrowers. It is also robust to the inclusion of several firm and loan characteristics.

It should be noted that notwithstanding the interaction between the crisis and PIIGS variables, PIIGS status in itself results in a generally lower loan spread and more favorable loan terms. That is, were the crisis not happen, PIIGS borrowers were still considered having higher creditworthiness than an average borrower. This important observation underpins the setback of banking globalization: prudential measures might be not adequately applied until it is too late. However, from the basis of our results, it is still difficult to ascertain as to how imprudent is the behavior of the banks.

With regards to mitigating the adverse effect of financial crises, counter-cyclical macroprudent approaches tend to be employed extensively nowadays, especially in world powerhouses such as the US and China (Cukierman \& Muscatelli, 2008; Chen, Funke, Lozev, \& Tsang, 2017). In times of reduced growth, governments tend to "enforce" bankers and encourage injection of capital to simulate investments. Our findings indicate that choosing the right borrowers to lend might not be an easy task. As can be seen, borrowers from troubled countries could very well be the downfall of lenders by means of spill-over financial instability and uncertainty. We leave the examination of such linkages for future research. 


\section{References}

Bharath, S., T, Sunder, J., \& Sunder, S., V. (2008). Accounting quality and debt contracting. The Accounting Review, 83(1), 1-28. doi: 10.2308/accr.2008.83.1.1

Brunnermeier, K., M. (2009). Deciphering the liquidity and credit crunch 2007-2008. The Journal of Economic Perspectives, 23(1), 77-100. doi: 10.1257/jep.23.1.77

Chava, S., Livdan, D., \& Purnanandam, A. K. (2009). Do shareholder rights affect the cost of bank loans? The Review of Financial Studies, 22(8), 2973-3004.

Chava, S., \& Purnanandam, A. (2011). The effect of banking crisis on bank-dependent borrowers. Journal of Financial Economics, 99(1), 116-135. doi: 10.1016/j.jfineco.2010 .08 .006

Chen, H., Funke, M., Lozev, I., \& Tsang, A. (2017). To guide or not to guide? quantitative monetary policy tools and macroeconomic dynamics in China. SSRN Electronic Journal, 1-45. doi: 10.2139/ssrn.2980537

Cukierman, A., \& Muscatelli, A. (2008). Nonlinear Taylor rules and asymmetric preferences in central banking: Evidence from the United Kingdom and the United States. The BE Journal of Macroeconomics, 8(1), 1-31. doi: 10.2202/1935-1690.1488

Diamond, W., D, \& Rajan, R. J. (2009). The credit crisis: Conjectures about causes and remedies. American Economic Review, 99(2), 606-610. doi: 10.1257/aer.99.2.606

Graham, J. R., Li, S., \& Qiu, J. (2008). Corporate misreporting and bank loan contracting. Journal of Financial Economics, 89(1), 44-61. doi: 10.1016/j.jfineco.2007.08.005

Hasan, I., Hoi, S., Wu, Q., \& Zhang, H. (2014). Beauty is in the eye of the beholder: The effect of corporate tax avoidance on the cost of bank loans. Journal of Financial Economics, 113(1), 109-130. doi: 10.1016/j.jfineco.2014.03.004

Ho, P. H., Huang, C. W., Lin, C. Y., \& Yen, J. F. (2016). Ceo overconfidence and financial crisis: Evidence from bank lending and leverage. Journal of Financial Economics, 120(1), 194-209. doi: 10.1016/j.jfineco.2015.04.007

Houston, J. F., Jiang, L., Lin, C., \& Y, M. (2014). Political connections and the cost of bank loans. Journal of Accounting Research, 52(1), 193-243. doi: 10.1111/1475-679x.12038

International Monetary Fund . (2011). Global financial stability report. Washington, DC: Grappling with crisis legacies. September. International Monetary Fund. doi: 10.5089/ 9781616351243.082

Ivashina, V., \& Scharfstein, D. (2010). Bank lending during the financial crisis of 2008. Journal of Financial Economics, 97(3), 319-338. doi: 10.1016/j.jfineco.2009.12.001

Lin, C., Y, M., Malatesta, P., \& Xuan, Y. (2011). Ownership structure and the cost of corporate borrowing. Journal of Financial Economics, 100(1), 1-23. doi: 10.1016/ j.jfineco.2010.10.012

Petersen, M. A. (2009). Estimating standard errors in finance panel data sets: Comparing approaches. The Review of Financial Studies, 22(1), 435-480.

Puri, M., Rocholl, J., \& Steffen, S. (2011). Global retail lending in the aftermath of the us financial crisis: Distinguishing between supply and demand effects. Journal of Financial Economics, 100(3), 556-578. doi: 10.1016/j.jfineco.2010.12.001

Raunig, B., Scharler, J., \& Sindermann, F. (2017). Do banks lend less in uncertain times? Economica, 84(336), 682-711. doi: 10.1111/ecca.12211 
Valencia, F. (2016). Bank capital and uncertainty. Journal of Banking E Finance, 69, 1-9. doi: 10.1016/j.jbankfin.2015.06.010

White, H. (1980). A heteroskedasticity consistent covariance matrix estimator and a direct test for heteroskedasticity. Econometrica: Journal of the Econometric Society, 48(4), 817838. doi: $10.2307 / 1912934$ 